\title{
The Success Factors of Mobile GPS Navigation Applications among Tourists in Malaysia
}

\author{
Fajar, M.S.B, Arshad, Y., Tahir, M.N.H., Syed Ibrahim, S.N.
}

\begin{abstract}
Smartphone users have increased tremendously in Malaysia in the last ten years. As smartphone users depend more on sophisticated and intelligent mobile devices to assist them in daily lives for better decision-making, this has prompted developers to develop more systems and applications suitable for them. One of the popular mobile applications for assisting travelers to locate their destinations is using Global Positioning System (GPS) technology. Regardless of any traveling purposes or types of users, these GPS navigation applications users prefer free or inexpensive, easy to access, and user-friendly systems and mobile applications. Google Maps is one of the freely available and popular applications that is used by around nine million users in the world. Researches on mobile applications developments were mostly based on Google Maps and its technology. Some of the recommendations by previous researchers include a further study on the factors that make Google Maps as a popular GPS navigation application in the world. Hence, this research targets to investigate the success factors of GPS navigation applications among smartphone users in Malaysia. A total of 402 tourists in Malaysia were selected to answer the questionnaires. The Statistical Package for Social Science (SPSS) analysis began with exploratory factor analysis to analyze the success factors and followed by multiple regression analysis to examine their relationships via hypotheses testing. The outcomes of the study revealed that system quality, information quality, perceived value, and perceived usefulness were significantly influencing user satisfaction. Therefore, this research helps future researches and software development company to understand in-depth details of the success factors of GPS navigation applications, as well the body of knowledge for satisfaction research for mobile applications.
\end{abstract}

Index Terms: GPS Navigations, Success Factors, Tourism, Malaysia.

\section{INTRODUCTION}

The application usage in a smartphone is popular as a result of a growing smartphone users that contribute to bigger demand for mobile applications (1). From several applications in the smartphone, one of the popular

Revised Manuscript Received on October 25, 2019

Fajar, M.S.B., Fakulti Pengurusan Teknologi dan Teknousahawanan (FPTT) and Centre of Technopreneurship Development (C-TeD), Universiti Teknikal Malaysia Melaka, Malaysia.

Arshad, Y., Centre of Technopreneurship Development (C-TeD) \& Fakulti Pengurusan Teknologi dan Teknousahawanan (FPTT), Universiti Teknikal Malaysia Melaka (UTeM), Malaysia. ayusri@utem.edu.my

Tahir, M.N.H., Centre of Technopreneurship Development (C-TeD) \& Fakulti Pengurusan Teknologi dan Teknousahawanan (FPTT), Universiti Teknikal Malaysia Melaka (UTeM), Malaysia.

Syed Ibrahim, S.N., Fakulti Perakaunan, Universiti Teknologi MARA Cawangan Melaka, Malaysia. applications is regarding the usage of GPS (Global Positioning System) for navigation purposes. The growth of GPS usage in mobile applications, especially for navigational purposes, has drastically increased in recent years (2) (3). Majority people utilize these GPS navigation applications for travel purposes (4). Among popular GPS navigation applications in smartphones such as Google Maps and Waze are used by more than one million users around the world (5) (6);(7). This study aims to investigate four objectives: 1) To investigate success factors of GPS navigation applications in the smartphone, 2) To identify the most influencing factor that affects user satisfaction of GPS navigation applications in the smartphone, 3 ) To identify the relationship between system quality, information quality, perceived value, perceived usefulness, toward user satisfaction of GPS navigation applications individually and as a whole, 4) To examine the effect experience of the relationship between system quality, information quality, perceived value, perceived usefulness and user satisfaction of GPS navigation applications.

\section{LITERATURE REVIEW}

Global Position System (GPS) is used to find the geometric positioning of the user that provide the data from longitude, latitude, and direction (8). GPS is owned by the United States Government to provide information for the users of their position, navigation, and time (9). GPS can be used in the Intelligent Transport System (ITS) for the route guidance (8), and to be used in mobile applications for a smartphone to avoid the congestion in real-time (10). GPS can be utilized in the mobile application on the smartphone for several purposes, such as navigation purposes. Navigation applications use GPS technology to provide additional information regarding the speed of the vehicle (8). For the navigation applications, there are several well-known applications with integrated GPS such as Google Maps, and Waze, and both of these applications are free to be downloaded and to be used in the smartphone (11)

\section{A. Factors on GPS Navigation as Mobile Applications Adoption, Continuance Intention, and Satisfaction}

The literature shows three factors that are commonly studied on mobile applications or systems, namely, system quality, service quality, and perceived usefulness related with satisfaction. In addition, other factors are attitude, perceived effectiveness, and self-efficacy associate with

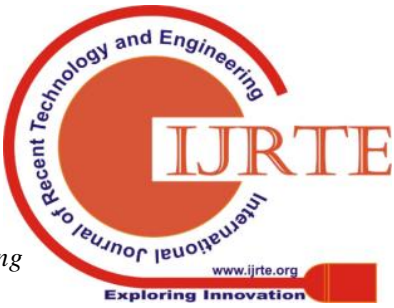




\section{The Success Factors of Mobile GPS Navigation Applications among Tourists in Malaysia}

adoption intention (12). Hence, based on the previous past study regarding factors on a mobile application in case of adoption, continuance intention, and satisfaction, this study concentrated on the following parameters that had been used by the majority of the reviewed researchers.

\section{1) System Quality $(S Q)$}

This is a quality that is measured through the features in the system or application (13). (12) reported that system quality in the aspects of mobile application acceptance is the reflection of constancy, trustworthiness, response time, and compatibility of applications. According to (14), system quality refers to facility of monitoring, learning, user interface, adequate system support, system response time, support decision making, easy access everywhere, fast and efficient communication support, security protection, and system privacy of mobile health application. (15) state that system quality of a website is measured using several aspects such as accessibility, usability, user-friendliness, and easy to navigate. (16) view system quality from mobile applications as the ease to navigate, ease of use, system reliability, and system functionality. (17) suggest that system quality aspects of Facebook as a mobile application in the system reliability, system design, and ease of use. In addition to these descriptions and measurements of system quality, another research by (13) report that system quality for mobile applications refers to response time, availability, system design, and system flexibility.

\section{2) Information Quality $(I Q)$}

It is a parameter of the information given to the consumer or user from systems such as website, as well as mobile applications (13). As reported by (14), information quality of mobile applications is measured through the ease of access, up to date, sufficiency, relevancy, accuracy, and usefulness of that information. (15) state that information quality refers to up to date, accuracy, relevancy, and completeness. (16) find that information quality of mobile applications is measured using usefulness, reliability, up to date, and completeness of information from mobile applications. (18) show that information quality of the mobile website is based on the content, format, accessibility, security, and privacy dimensions of the information. (19) substantiates this by providing evidence of information quality relating to the accuracy, timeliness, broadness, and relevancy of the information. (17) reveal that information quality of mobile applications is measured through content usefulness and quality. Previously, (13) find that information quality of mobile applications refers to the accuracy, relevancy, easy to understand, and completeness.

\section{3) Perceived Value (PV)}

According to the ACSI model theory by (20), PV is a level of perception toward the product or service quality as compared to the paid price. PV has a positive effect on client happiness that leads to his loyalty and complaint of mobile phone user in Jordan (21). Several researchers have empirically established that PV has a major and positive effect on customer satisfaction to use a product or service
(22)(23). In recent studies, PV is accounted as one of the explanatory variables for the satisfaction for mobile application's user as well. For example, (24) demonstrate that PV have a important and positive influence on the satisfaction of mobile social media user and (25) report that perceived value has a significant impact on the satisfaction of mobile application's user. The effect of perceived value has been positively influenced user satisfaction in the case of smartphone usage (1) and mobile application usage (26).

\section{4) Perceived Usefulness (PU)}

Perceived usefulness is an understanding of the outcome of utilizing a system which can facilitate the user objective from an activity, which is claimed to be useful (13)(12). According to (27), perceived usefulness of mobile applications refers to overall usefulness, enhance effectiveness, increase productivity, and improve performance after the usage of mobile applications. (28) suggest that perceived usefulness reflects overall usefulness, decrease time consumption, and improve performance. (29) state that, perceived usefulness is measured through increase productivity, improve performance, and enhance effectiveness after the usage of mobile applications. (30) and (31) reported that perceived usefulness for mobile applications covers the enhanced effectiveness, increased productivity, ease of access, and overall usefulness. Moreover, (13) also show that perceived usefulness of mobile applications refer to the improved performance, ease of access, increased productivity, enhanced effectiveness, and overall usefulness after the usage of applications.

\section{5) User's Satisfaction}

According to the IS success model theory, User's satisfaction is affected by the system and information quality after the usage of the system, technology, or applications (32). Many researchers studied satisfaction as the research topic because there are many demands for this knowledge. User's satisfaction is the specific area resulted from the increasing number of smartphone users (13)(33). Recently, (12) study user's behavior of mobile applications related to the user's satisfaction of Telegram messenger in Iran. In addition, (34) examines the user's satisfaction of the mobile shopping application that related to the loyalty of the user. Other subtopics are the consequence of mobile banking acceptance toward customer interaction and satisfaction (35), the satisfaction of the customer and repatronage intention after the usage of retailers' mobile application (36) and the effect of mobile learning toward the satisfaction of the student, then also to identify the internal and external factors that affect mobile learning (37).

(29) investigate the influential factors for the continuance practice of mobile social applications that related to user satisfaction and habit. Later, (38) discuss the relationship between the mobile banking benefits and user satisfaction that mediates toward the trust, loyalty, and positive word-of-mouth. (39) examine the interaction benefits from branded mobile applications toward user satisfaction and

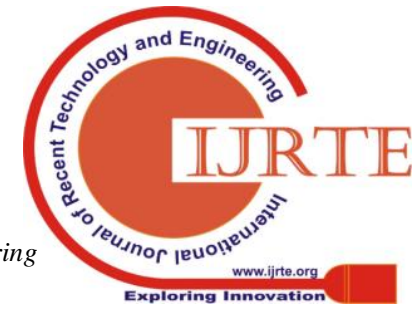


purchase intentions. In the same year, (18) study information quality and usefulness of the Islamic e-Tourism website toward the information satisfaction of the user. Other related studies are by (31) on the satisfaction of the life insurers applications service user is studied, by (40) and (25) on the impacts of mobile applications towards the user performance and satisfaction, and also the relationship between user engagement, perceived value, and satisfaction, by (17) on the factor affecting user satisfaction of Facebook as mobile applications, and by (13) on the satisfaction and continuance intention from InstaFind application's user. These studies indicate that the user's satisfaction has been vigorously studied by researchers and thus, using it as the dependent variable is strongly supported by the literature.

\section{B. Theoretical Framework and Hypotheses}

From the literature review, this study had developed a theoretical framework in Figure 1 to analyse four independent variables on user satisfaction of using GPS navigation system. Moderating variable experience was included in the original study to analyse the impact of moderator among the variables. However, the result of moderating analysis is reported in another publication. Four hypotheses were formulated from $\mathrm{H} 1, \mathrm{H} 2, \mathrm{H} 3$ and $\mathrm{H} 4$.

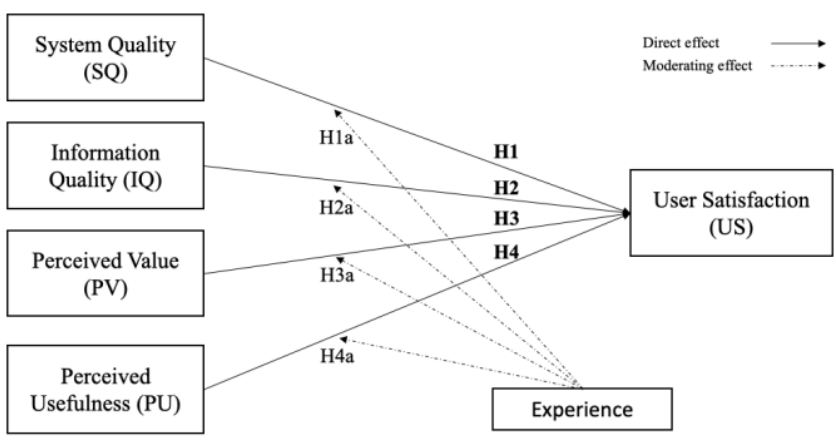

Fig. 1. Theoretical framework

\section{METHODOLOGY/MATERIALS}

Information system researches focus mainly on quantitative, qualitative or mixed method designs. This research implemented quantitative survey method for data gathering and analysis. The study sample covered both local and international tourists registered in Malaysia tourism. Total population of respondents for local and international registered tourists in 2018 was on average 29.41 million and 25.16 million respectively. Thus, the suitable sample size according to (41) is 384 samples.

The questionnaire was developed based on past researches with a minor modification to suit the feedbacks from the pre-test and pilot study (49). Among the popular destinations visited by local tourists were Langkawi, Penang, Cameron Highland in Perak, Kuala Lumpur, Melaka, Johor Baharu, Kota Bharu and Kuala Terengganu. International tourists visited Kuala Lumpur, Langkawi, Penang, Melaka and popular islands in the East and Southern West Malaysia.

A total of 402 returned replies were analysed. The value for KMO-MSA was 0.922 which higher than 0.6 standards from Pallant (2016) and 0.8 standards from (42). This value

was considered as meritorious or worthwhile. The approximate of Chi-square was 2289.304 with 171 degrees of freedom. The value of Bartlett's test was counted as significant because the value was lower than 0.05 . Then, the variable's value was accepted because it met the standard from the past known studies.

\section{RESULTS AND FINDINGS}

\section{A. Descriptive Analysis}

Cronbach's Alpha coefficient was commonly used to measure the consistency of constructs. (42) state that if Cronbach's Alpha value was more than 0.7 or at least more than 0.6 , the variable was considered reliable and could be used in the study. The result in table 4.8 showed Cronbach Alpha from the 402 samplings for system quality (4 items) was 0.632 , information quality (5 items) was 0.725 , perceived value ( 3 items) was 0.727 , perceived usefulness (4 items) was 0.650 , and user satisfaction (3 items) was 0.740 . Hence, all variables were considered had high reliability and therefore, were acceptable for this research.

Majority of the gender for the survey was male with 210 people and female with 192 people. The highest age group percentage was between $15-24$ years old $(72.1 \%)$, followed by $25-34$ years old (21.9), then $35-44$ years old ( $4.7 \%)$, after that below 15 years old $(1.0 \%)$, and the lowest age group percentage was between $45-54$ years old $(0.2 \%)$. There was not any respondent from the age group of 55-64 years old $(0 \%)$, and 65 years old and above $(0 \%)$. The result showed $68.2 \%$ had an undergraduate background, $20.6 \%$ had high school and below background, and finally the postgraduate background with $11.2 \%$. Majority of the respondents were domestic tourists with 248 people $(61.7 \%)$, followed by international tourists with 154 people (38.3\%). All the 402 tourists who answered the questionnaire owned a smartphone and had used GPS navigation applications in their smartphone. The results also found that additional GPS navigation applications were Apple Maps $(0.5 \%)$, and Here WeGo $(0.2 \%)$. The most used GPS navigation applications were Google Maps (52\%), followed by Waze (44.5\%), then Maps.Me (2.7\%), and unexpectedly no respondent for Sygic user.

Table 1. Descriptive Analysis Results

\begin{tabular}{lcc}
\hline Variables & Mean & SD \\
\hline System Quality & $\mathbf{4 . 0 5 7}$ & $\mathbf{0 . 5 2 5}$ \\
\hline $\begin{array}{l}\text { GPS navigation applications that I use is } \\
\text { responsive (Fast loading time) }\end{array}$ & 4.06 & 0.719 \\
$\begin{array}{l}\text { GPS navigation applications is } \\
\text { user-friendly and understandable (User } \\
\text { friendly) }\end{array}$ & 4.26 & 0.627 \\
$\begin{array}{l}\text { GPS navigation application is not crash } \\
\text { (Error) easily }\end{array}$ & 3.81 & 0.892 \\
& &
\end{tabular}


There are many functionality in GPS navigation applications that I can use apart from navigation (Example: Bookmark a place, report situation, route for walking, etc.)

\begin{tabular}{|c|c|c|}
\hline Information Quality & 3.980 & 0.542 \\
\hline $\begin{array}{l}\text { The place or address that I search in GPS } \\
\text { navigation applications is appear in the } \\
\text { search result }\end{array}$ & 4.05 & 0.718 \\
\hline $\begin{array}{l}\text { The place or address from the search result } \\
\text { in GPS navigation applications is } \\
\text { up-to-date }\end{array}$ & 4.00 & 0.783 \\
\hline $\begin{array}{l}\text { The place or address that shown in GPS } \\
\text { navigation applications is accurate }\end{array}$ & 3.98 & 0.734 \\
\hline $\begin{array}{l}\text { The search result for place or address } \\
\text { function in GPS navigation applications is } \\
\text { quick (Fast loading time) }\end{array}$ & 4.02 & 0.749 \\
\hline $\begin{array}{l}\text { All the place or address around me is } \\
\text { available in GPS navigation applications }\end{array}$ & 3.84 & 0.926 \\
\hline Perceived Value & 4.141 & $\mathbf{0 . 5 8 7}$ \\
\hline $\begin{array}{l}\text { GPS navigations applications provide high } \\
\text { quality system with free of charge }\end{array}$ & 4.18 & 0.722 \\
\hline $\begin{array}{l}\text { GPS navigations applications provide } \\
\text { details and up-to-date information with free } \\
\text { of charge }\end{array}$ & 4.13 & 0.745 \\
\hline $\begin{array}{l}\text { The overall value of using GPS navigation } \\
\text { applications is outstanding and meet my } \\
\text { desire }\end{array}$ & 4.11 & 0.722 \\
\hline Perceived Usefulness & 4.254 & 0.498 \\
\hline $\begin{array}{l}\text { Using GPS navigation applications let me } \\
\text { use the faster route when traveling }\end{array}$ & 4.12 & 0.808 \\
\hline $\begin{array}{l}\text { Using GPS navigation applications } \\
\text { increase the probability to reach a place or } \\
\text { address that I never been there before while } \\
\text { traveling }\end{array}$ & 4.24 & 0.696 \\
\hline $\begin{array}{l}\text { Using GPS navigation applications let me } \\
\text { estimate the time and distance that I will } \\
\text { spend to reach specific place or address }\end{array}$ & 4.25 & 0.665 \\
\hline $\begin{array}{l}\text { Overall, GPS navigation applications is } \\
\text { useful for me }\end{array}$ & 4.41 & 0.672 \\
\hline User Satisfaction & 4.187 & $\mathbf{0 . 5 3 8}$ \\
\hline $\begin{array}{l}\text { I am satisfied with GPS navigation } \\
\text { applications that meet my expectation } \\
\text { which fulfil my need }\end{array}$ & 4.21 & 0.680 \\
\hline $\begin{array}{l}\text { I am satisfied with GPS navigation } \\
\text { applications based on the time that I spent }\end{array}$ & 4.11 & 0.671 \\
\hline $\begin{array}{l}\text { I feel pleased and satisfied with the overall } \\
\text { experience when using GPS navigation } \\
\text { applications }\end{array}$ & 4.23 & 0.636 \\
\hline
\end{tabular}

For system quality, the mean ranged between 3.81 and 4.26. GPS navigation application was easy to use and understandable (user-friendly) had the highest mean score, followed by the GPS navigation applications had many functionalities apart from the navigation, responsiveness for the GPS navigation applications including fast loading time and lastly, the system quality, measured by the crash frequency for the GPS navigation applications.

For information quality, the mean ranged from 3.84 to 4.05. The highest mean score was the place or address searched in GPS navigation applications was shown in the search result. The second highest mean was the loaded time for a search result for a place or address in GPS navigation applications was fast, and followed by the place or address from the search result in the GPS navigation applications was up-to-date, the accuracy of the place or address in GPS navigation application and the least mean was the availability of place, landmark, or address around the GPS navigation application's user was shown.

Perceived value had a mean ranged within 4.11 to 4.18 . GPS navigations applications provide a high-quality system with free of charge had the highest mean score. The list of other item for perceived value ranked by their mean scores were PS navigations applications provided details and up-to-date information with free of charge, and the overall value when used GPS navigation applications was outstanding and meet the user desire.

For the perceived usefulness, the mean ranged within 4.12 to 4.41 which were higher compared to the other variables mean. The highest mean was the overall usefulness of GPS navigation applications for the user. Followed by the usage of GPS navigation applications let the user to estimate the time and distance needed to reach the specific place or address, the usage of GPS navigation applications increased the probability to reach a place or address for the user, and finally, the usage of GPS navigation applications let the user used the fastest route for travel.

For the dependent variable, (user satisfaction) as the dependent variable, the ranged for the mean was 4.11 to 4.23. The highest score for mean was from item number 3 (mean: 4.23; SD: 0.636), which was the satisfaction for the overall experiences for the usage of GPS navigation applications. Followed by item number 1 (mean: 4.21; SD: 0.680), which was the satisfaction for the usage of GPS navigation applications that met the user expectation and need. And the last item with the least mean was item number 2 (mean: 4.11; SD: 0.671), which was the satisfaction for the usage of GPS navigation applications based on the time that spent. Hence, those results showed that the variables had high scores for the GPS satisfaction success factors among domestic and international tourists. Since GPS navigation had been used in a few years that increased the sophistication for application such as Google Maps and Waze intelligent features, users rely heavily on the applications for finding directions of their destinations.

\section{B. Correlation Analysis}

Table 2. Pearson Correlation Analysis Results

\begin{tabular}{|c|c|c|c|c|c|}
\hline Scale & 1 & 2 & 3 & 4 & 5 \\
\hline 1. System Quality & - & & & & \\
\hline $\begin{array}{l}\text { 2. Information } \\
\text { Quality }\end{array}$ & $0.616 *$ & - & & & \\
\hline 3. Perceived Value & $0.513 *$ & $0.531 *$ & - & & \\
\hline
\end{tabular}


4. Perceived

Usefulness

$0.557 * 0.482 * 0.538 *$

5. User Satisfaction $0.528 * 0.572 * 0.523 * 0.586 *$ -

$* \mathrm{p}<0.05$ (2-tailed).

Table 2 shows the results from Pearson correlation analysis. The correlation of each variable to the others variable was relatively in the significant correlation coefficients.

\section{Regression Analysis}

Table 3. Model Summary

\begin{tabular}{ccccc}
\hline Model & R & R Square & $\begin{array}{c}\text { Adjusted } \\
\text { R Square }\end{array}$ & $\begin{array}{c}\text { Std. Error of } \\
\text { the Estimate }\end{array}$ \\
\hline 1 & 0.690 & 0.477 & 0.471 & 0.39081 \\
\hline
\end{tabular}

Predictors: (Constant), Perceived Usefulness, Information Quality, Perceived Value, System Quality

Table 3 above shows key results for the research model. These results show that the explanatory variables such as system quality, information quality, perceived value, and perceived usefulness had a statistically significant relationship with the user's satisfaction of GPS navigation applications. The $\mathrm{R}^{2}$ for the model was 0.477 , which implied that 47.7 percent of the variation in user's satisfaction of GPS navigation applications was explained by these independent variables.

Table 4. Coefficient Results for User's Satisfaction

\begin{tabular}{|c|c|c|c|c|c|}
\hline \multirow[t]{2}{*}{ Model } & \multicolumn{2}{|c|}{$\begin{array}{c}\text { Unstandardiz } \\
\text { ed } \\
\text { Coefficients }\end{array}$} & $\begin{array}{c}\text { Standa } \\
\text { rdized } \\
\text { Coeffic } \\
\text { ients }\end{array}$ & \multirow[t]{2}{*}{$\mathbf{t}$} & \multirow[t]{2}{*}{ Sig. } \\
\hline & B & $\begin{array}{l}\text { Std. } \\
\text { Erro } \\
\text { r }\end{array}$ & Beta & & \\
\hline (Constant) & 0.645 & 0.189 & & 3.412 & 0.001 \\
\hline $\begin{array}{l}\text { System } \\
\text { Quality }\end{array}$ & 0.107 & 0.052 & 0.105 & 2.076 & 0.039 \\
\hline 1 Information & 0.273 & 0.049 & 0.275 & 5.627 & 0.000 \\
\hline $\begin{array}{l}\text { Perceived } \\
\text { Value }\end{array}$ & 0.142 & 0.043 & 0.155 & 3.300 & 0.001 \\
\hline $\begin{array}{l}\text { Perceived } \\
\text { Usefulness }\end{array}$ & 0.337 & 0.051 & 0.312 & 6.635 & 0.000 \\
\hline
\end{tabular}

Table 4 presents the correlation coefficients for each explanatory variable. All correlation coefficients were statistically significant at 5\% significant level. Perceived usefulness had the strongest relation with the user's satisfaction. It meant that for every one increasing unit in perceived usefulness, user's satisfaction would increase by 37.2 percent. The smallest correlation coefficient was between system quality and the user's satisfaction, at 0.105 with p-value less than 0.05 .
From the multiple regression analysis, using the standardized correlation coefficients, the regression equation for the study was: User Satisfaction of GPS navigation application $=0.107$ (system quality) +0.273 (information quality) +0.142 (perceived value) +0.337 (perceived usefulness) +0.645 .

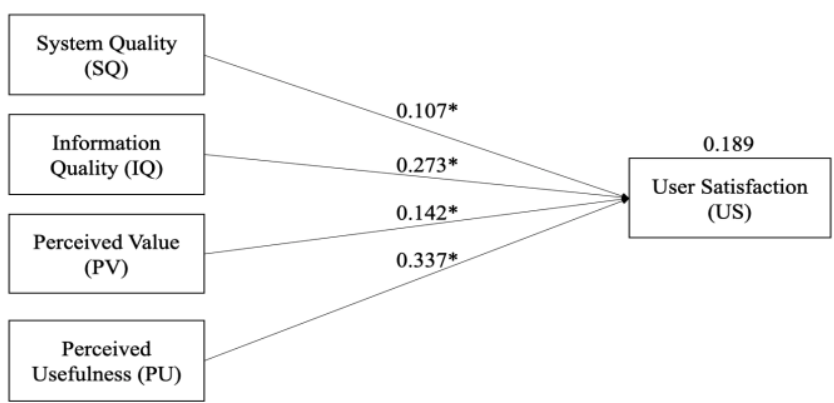

Fig. 2. Hypotheses Results Diagram

\section{Hypotheses Testing}

There were four hypotheses for the independent variable. The first hypothesis (H1) was system quality significantly affected the user satisfaction of GPS navigation applications. The second hypothesis (H2) was information quality significantly influenced the user satisfaction of GPS navigation applications. The third hypothesis (H3) was perceived value significantly affected the user satisfaction of GPS navigation applications. The fourth hypothesis (H4) was perceived usefulness significantly affected the user satisfaction of GPS navigation applications.

Table 5. Multiple Regression Analysis for Hypotheses Testing

\begin{tabular}{|c|c|c|c|c|}
\hline & \multirow[t]{2}{*}{ Variables } & \multicolumn{3}{|c|}{$\begin{array}{c}\text { Regression Models } \\
\text { (User Satisfaction of GPS } \\
\text { Navigation Applications) }\end{array}$} \\
\hline & & B & Sig & Results \\
\hline H1 & System Quality & 0.107 & $0.039 *$ & Supported \\
\hline $\mathrm{H} 2$ & Information Quality & 0.273 & $0.000^{*}$ & Supported \\
\hline H3 & Perceived Value & 0.142 & $0.001 *$ & Supported \\
\hline $\mathrm{H} 4$ & Perceived Usefulness & 0.337 & $0.000^{*}$ & Supported \\
\hline & $\mathrm{R}^{2}$ & \multicolumn{2}{|c|}{0.477} & \\
\hline & Adjusted $\mathrm{R}^{2}$ & \multicolumn{2}{|c|}{0.471} & \\
\hline & $\mathrm{F}$ & \multicolumn{2}{|c|}{90.434} & \\
\hline
\end{tabular}

Table 5 shows that multiple regression analysis results for the independent variables (system quality, information quality, perceived value, perceived usefulness). These independent variables explained $47.7 \%$ of the variance in the user's satisfaction of GPS navigation application. System quality ( $\beta=0.107, p=0.039$ ) was significantly related to the user satisfaction of GPS navigation applications. Therefore, $\mathrm{H} 1$ was supported. Information quality $(\beta=0.273, \mathrm{p}=$ 0.000) had a significant relationship with the user's satisfaction of GPS navigation applications. Hence, $\mathrm{H} 2$ was 
supported. Perceived value $(\beta=0.142, \mathrm{p}=0.001)$ was also having a significant relationship with the user's satisfaction of GPS navigation applications. Thus, H3 was supported. Lastly, perceived usefulness $(\beta=0.337, \mathrm{p}=0.000)$ was significantly related to the user's satisfaction of GPS navigation applications. Therefore, $\mathrm{H} 4$ was supported too.

\section{DISCUSSION AND RESEARCH FINDINGS}

This section discusses the results and findings from the study. Table 6 depicts the results for the first research objective.

System quality was one of the success factors for the satisfaction of GPS navigation application's user. For GPS navigation applications such as Google maps and Waze, the system quality factors were shown through the responsiveness of the applications whether the loading time was fast enough, then through user-friendliness that made the user easy for using the application. The more effort the application developer put on ease of use of an application, the easier for a user to be satisfied (43).

Table 6. First Research Question and Objective

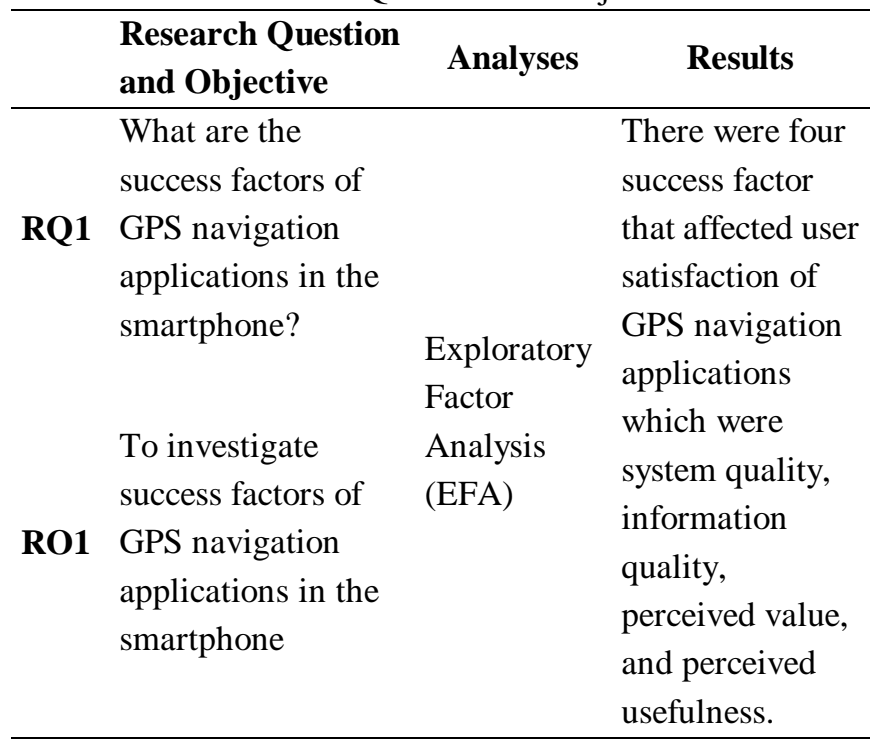

Next, it was shown through the accessibility of the applications by checking how often the crash or error happened, and the last through the functionality inside the applications that useful for the user. Improvement in system quality of the application would lead to better performance and useful for the competitive advantage between application developer (44). (13), (17) agree with the system quality as one the factor to determine user's satisfaction in applications. The system quality was part of the GPS navigation application that contributes the first effect to its user since in smartphone the user engaged with various applications which could be compared for the quality of the system in general. Therefore, the system quality of the GPS navigation applications was sufficient in term of the responsiveness, user-friendliness, accessibility, and functionality for the user to be satisfied.

The next success factor for the satisfaction of the GPS navigation application user was information quality. For
GPS navigation applications such as Google Maps and Waze, the information quality were demonstrated in priority order via the relevancy of the search result in the applications, the up to date information in the applications, the accuracy of the location that is shown in the application, timeliness of the information in the application reached the user that in terms of the loading time, and finally the completeness of the information regarding the address and place that were shown in the application. It was necessary for GPS navigation applications to have a good quality of information that accurate, short loading time, and complete for the satisfaction of the user (13) (19). (45) state that information quality in online form was the factor for the user to rate whether the applications usable or not. In tourism applications, it was required for the information quality to be relevant, legitimate, and reliable for the user to use the applications, and feel satisfied with the applications (18). Therefore, the information quality of GPS navigation applications was adequate in term of the relevancy, up to date, accuracy, timeliness, and completeness for the user to be satisfied.

For perceived value as one of the success factors of GPS navigation applications such as Google Maps and Waze, it was important to become an application that valuable for the user in order to satisfy. The perceived value of GPS navigation applications was based on the high-quality system application with a low-price requirement, good service of the application through the details and up to date information with reasonable price, and easy to meet the desire of the user. Perceived value was an important factor that affects user's satisfaction with the smartphone and applications based on the time and money that the user spent (1)(25). (46) suggested that the satisfaction of the user or consumer was measured through the value of the applications whether it provided good service for a reasonable price, had high quality for low price requirement, and meet the need of the user or consumer. For GPS navigation applications that were used by the respondents in this research which were Google Maps, Waze, Maps.Me, Apple Maps, and Here WeGo, these applications were free to download in smartphone for any operating system (Android, IOS), except for Apple Maps that only available in IOS. Therefore, the perceived value of GPS navigation applications in term of low-price requirement for high-quality system, good information for a reasonable price, and deliver user desired, was considered valuable for the user to be satisfied.

The last success factor for user satisfaction of GPS navigation applications was perceived usefulness. For GPS navigation applications such as Google Maps, and Waze, the perceived usefulness was shown through provided the user with a faster route to increase the productivity, increase the performance by increasing the probability of the user to reach a place or address inside the applications, then allowed the user to use the applications as a useful tool to estimate the time and distance to reach a place or address, and the

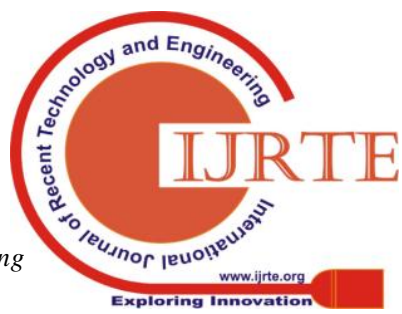


overall usefulness of the application for the user. The applications on the smartphone were made by the developer with a purpose to be useful for the user that might help with various tasks (47)(31). It was necessary for the applications to provide functionality and information that useful which made the work or assignment easier for the user (30). (40), and (48) reported that applications or system should increase the productivity and made the task easier to be completed for a user to be considered as perceived usefulness factors. Therefore, the perceived usefulness of GPS navigation applications in term of providing a faster route that increase productivity, increase user performance, a tool to estimate time and distance and overall usefulness of the applications, was considered useful for the user to be satisfied.

Based on Table 7, the most influencing success factor that affected user satisfaction of GPS navigation application was perceived usefulness. (30) proposed that perceived usefulness was the variable with the highest factor loading which means perceived usefulness was the most influencing factor for the mobile website customer's satisfaction compared with perceived ease of use, and trust.

Table 7. Second Research Question and Objective

Research
Question and Analyses Results
Objective

What is the most

influencing factor

that affects user

RQ2 satisfaction in GPS

navigation

applications in the

smartphone?

To identify the

most influencing

factor that affects

RO2 user satisfaction of

GPS navigation

applications in the

smartphone.

From the exploratory factor analysis (EFA), this study found that the three highest loading value was from perceived usefulness variable item number two, four, and three. From those rankings, it could be interpreted that GPS navigation applications such as Google Maps and Waze had increased the user performance by enhancing the probability to reach a destination when using the applications. Subsequently, GPS navigation applications proved to be appreciated by the user for the overall usefulness. The user of GPS navigation applications had realized the usefulness of the function to estimate the time consumption and distance traveled. Those three components of perceived usefulness proven to be the most influencing questions that affected user satisfaction of GPS navigation applications.

Table 8. Third Research Question and Objective

\begin{tabular}{|c|c|c|c|}
\hline & $\begin{array}{l}\text { Research Question } \\
\text { and Objective }\end{array}$ & Analyses & Results \\
\hline RQ3 & $\begin{array}{l}\text { What is the } \\
\text { relationship between } \\
\text { system quality, } \\
\text { information quality, } \\
\text { perceived value, } \\
\text { perceived usefulness, } \\
\text { toward user } \\
\text { satisfaction of GPS } \\
\text { navigation } \\
\text { applications } \\
\text { individually and as a } \\
\text { whole? } \\
\text { To identify the } \\
\text { relationship between } \\
\text { system quality, } \\
\text { information quality, } \\
\text { perceived value, } \\
\text { perceived usefulness, } \\
\text { toward user } \\
\text { satisfaction of GPS } \\
\text { navigation } \\
\text { applications } \\
\text { individually and as a } \\
\text { whole. }\end{array}$ & $\begin{array}{l} \\
\text { Linear } \\
\text { Regression } \\
\text { Analysis } \\
\text { and } \\
\text { Multiple } \\
\text { Regression } \\
\text { Analysis } \\
\text { (MRA). }\end{array}$ & $\begin{array}{l}\text { System quality, } \\
\text { information } \\
\text { quality, } \\
\text { perceived value, } \\
\text { perceived } \\
\text { usefulness had } \\
\text { significant } \\
\text { relationship with } \\
\text { the user } \\
\text { satisfaction of } \\
\text { GPS navigation } \\
\text { applications } \\
\text { individually and } \\
\text { as a whole. }\end{array}$ \\
\hline
\end{tabular}

Table 8 showed that for the third research objective, all the independent variables had significant relationship with the dependent variable individually and as a whole. For system quality and user satisfaction, every unit increase in system quality, the user satisfaction would increase 54.0 percent, which could be concluded that system quality had a significant positive relationship with the user satisfaction ( $p$ $=0.000)$. In addition, for information quality and user satisfaction, the result showed that for every unit increase in information quality, the user satisfaction would increase 56.8 percent, which could be concluded that information quality had a significant positive relationship with the user satisfaction $(\mathrm{p}=0.000)$.

Based on the linear regression results between perceived value and user satisfaction, every unit increase in perceived value, the user satisfaction would increase 47.9 percent, which could be concluded that perceived value had a significant positive relationship with the user satisfaction ( $p$ $=0.000$ ). The result also showed for every unit increase in perceived usefulness, the user satisfaction would increase 63.4 percent, which could be concluded that perceived usefulness had a significant positive relationship with the user satisfaction $(\mathrm{p}=0.000)$.

Based on the multiple regression analysis for all independent variables with the dependent variables, the results showed that for system quality, every increasing unit in system quality, the user

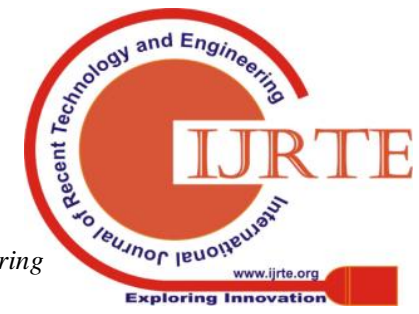


satisfaction would increase 10.7 percent, with a significant positive relationship $(\mathrm{p}=0.039)$. Then for information quality, every increasing unit in information quality, the user satisfaction would increase 27.3 percent, with a significant positive relationship $(\mathrm{p}=0.000)$. After that for perceived value, every increasing unit in perceived value, the user satisfaction would increase 14.2 percent, with a significant positive relationship $(\mathrm{p}=0.001)$. And for the last variable which was perceived usefulness, every increasing unit in perceived usefulness, the user satisfaction would increase 33.7 percent, with a significant positive relationship $(\mathrm{p}=$ 0.000).

Multiple regression analysis produced results that statistically supported the research hypothesis. System quality had significantly affected the user satisfaction of GPS navigation applications (H1). This substantiates previous research such as system quality influences the satisfaction of Facebook mobile application (17), and that system quality positively associated with confirmation which leads to the satisfaction of mobile applications (13).

The second hypothesis was also statistically supported. This study finds that information quality has significant influence on the user's satisfaction of GPS navigation applications (H2). This finding is consistent with prior studies. For instance, (45) show that information quality in online form had strong positive influenced to the consumer satisfaction with the website, and (19) infers that information quality dimension positively affected customer satisfaction in the E-Banking services.

This study finds similar results for the third hypothesis. Perceived value was also significantly affected the user satisfaction of GPS navigation applications (H3). Previous research shows consistent findings. (22) finds that perceived value had a positive influence on customer satisfaction and post-purchase intention in mobile added-value services. In addition, (1) reveal that perceived value positively influence the satisfaction of smartphone user. Meanwhile, (25) state that perceived value had a significant impact on customer satisfaction for the mobile applications.

The fourth and last hypothesis was supported too. This study can infer that perceived usefulness had significantly affected the user's satisfaction of GPS navigation applications (H4). Existing studies provide similar findings such as (30) where their research finding was the perceived usefulness positively related to the trust and mobile user satisfaction, (31) indicated that consumer perceived usefulness positively affected customer satisfaction of mobile application service in the life insurance industry. (47) and (40) found that perceived usefulness was positively associated to enhance the user satisfaction of the mobile applications.

\section{CONCLUSION}

Global Positioning System (GPS) was a well-known system, especially for navigation purposes. Past researchers showed that GPS usage in transportation businesses grew rapidly in recent years and there was a significant improvement for the safety and monitoring because it could avoid transportation problems such as road accidents and traffic jam. In addition, drivers, particularly tourists, often needed some additional technology assistance such as voice-guided navigation applications to locate their destinations easily. Nowadays, young travelers such as students preferred to download map application and used the GPS navigation applications in their smartphone when they travelled the cities. Most common reason for using navigational app is due to long queue and traffic jams in famous tourist destinations that are caused by an increased number of self-driving tourists. Due to this reason, applications such as Dr. What-Info and Smart City World Heritage that provided location-based services and Google Maps based information application for tour guiding and providing tourism information and also acting as a navigation device to go to registered tourism places in the application were invented.

First, this study investigated success factors of GPS navigation applications in the smartphone. Based on the literature review, this research utilized four factors of GPS navigation applications satisfaction which were system quality, information quality, perceived value, and perceived usefulness. To investigate those factors, questionnaires had been distributed to get data from tourists in Malaysia, which then analyzed using exploratory factor analysis (EFA). The findings suggested that system quality, information quality, perceived value, and perceived usefulness significantly affected the user satisfaction of GPS navigation applications.

Second study objective was to identify the most influencing factor that affected user satisfaction of GPS navigation applications in the smartphone. By using EFA and correlation analysis, the finding revealed that perceived usefulness was the most influencing factor that affected user satisfaction of GPS navigation applications in the smartphone. Perceived usefulness had the highest loading value in EFA and the highest large correlation with a strong positive relationship with user satisfaction in the correlation analysis.

Third, this study assessed the relationships between system quality, information quality, perceived value, perceived usefulness, toward user satisfaction of GPS navigation applications individually and as a whole. By using linear regression and multiple regression analysis, the findings indicated that system quality, information quality, perceived value and perceived usefulness had a significant positive relationship with the user satisfaction of GPS navigation applications in a smartphone.

As technology is changing very fast, new gadgets and applications are invented to cater to changes in the demographic and sociocultural. Future studies can examine user's satisfaction of other type of navigation applications, as well as newer smartphone models.

\section{Published By:}

Blue Eyes Intelligence Engineering

\& Sciences Publication

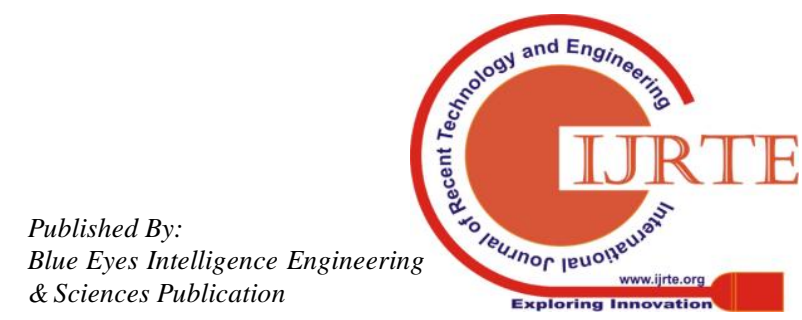




\section{ACKNOWLEDGEMENT:}

The authors would like to thank Fakulti Pengurusan Teknologi dan Teknousahawanan (FPTT), Centre for Technopreneurship Development (CTeD), Centre of Postgraduate Studies and Universiti Teknikal Malaysia Melaka for kind assistance throughout the entire course of MSc study. Without all the helps from supervisors, professors, lecturers, families, friends and respondents, this study would not have been possible. A special thank to Dr. Sharifah Norhafiza for the proofreading rendered for this article.

\section{REFERENCES}

[1] Kim YH, Kim DJ, Wachter K. A study of mobile user engagement (MoEN): Engagement motivations, perceived value, satisfaction, and continued engagement intention. Decis Support Syst. 2013;56:361-70.

[2] Yang S-Y, Hsu C-L. A location-based services and Google maps-based information master system for tour guiding. Comput Electr Eng. 2016;54:87-105.

[3] Zhou Z, Dou W, Jia G, Hu C, Xu X, Wu X, et al. A method for real-time trajectory monitoring to improve taxi service using GPS big data. Inf Manag. 2016;53(8):964-77.

[4] Lee S, Tewolde G, Kwon J. Design and implementation of vehicle tracking system using GPS/GSM/GPRS technology and smartphone application. In: 2014 IEEE world forum on internet of things (WF-IoT). IEEE; 2014. p. 353-8.

[5] Rouse M. What is Google Maps? - Definition from WhatIs.com. 2013;

[6] Klosowski T. Turn-by-Turn Navigation Showdown: Google Maps vs. Waze. 2016;

[7] Mobile W. Free Community-based Mapping, Traffic \& Navigation App. 2017;

[8] Binjammaz T, Al-Bayatti A, Al-Hargan A. GPS integrity monitoring for an intelligent transport system. In: 2013 10th Workshop on Positioning, Navigation and Communication (WPNC). IEEE; 2013. p. 1-6.

[9] Office N. GPS.gov: GPS Overview. 2016;

[10] Dhar J, Garg G. Real time traffic congestion detection and optimal path selection using smartphone. In: 2014 6th IEEE Power India International Conference (PIICON). IEEE; 2014. p. 1-6.

[11] McLaughlin M. The Best Free GPS Apps for Your iPhone. 2016;

[12] Hajiheydari N, Ashkani M. Mobile application user behavior in the developing countries: A survey in Iran. Inf Syst. 2018;77:22-33.

[13] Chen L, Meservy TO, Gillenson M. Understanding information systems continuance for information-oriented mobile applications. Commun Assoc Inf Syst. 2012;30(1):9.

[14] Handayani PW, Meigasari DA, Pinem AA, Hidayanto AN, Ayuningtyas D. Critical success factors for mobile health implementation in Indonesia. Heliyon. 2018;4(11):e00981

[15] McKnight DH, Lankton NK, Nicolaou A, Price J. Distinguishing the effects of B2B information quality, system quality, and service outcome quality on trust and distrust. J Strateg Inf Syst. 2017;26(2):118-41.

[16] Tam C, Oliveira T. Understanding the impact of m-banking on individual performance: DeLone \& McLean and TTF perspective. Comput Human Behav. 2016;61:233-44.

[17] Özata FZ. Determinants of user satisfaction with mobile applications: case of facebook as a mobile app in Turkey. In: Proceedings of Business and Management Conferences. International Institute of Social and Economic Sciences; 2015.

[18] Samsi M, BT SZ, Jamaluddin H, Noor M, Shabrina A, Mohd H, et al. Information Quality, Usefulness and Information Satisfaction in Islamic E-Tourism Websites. J Theor Appl Inf Technol. 2016;89(2).

[19] Ayyash MM. Identifying information quality dimensions that affect customers satisfaction of e-banking services. J Theor Appl Inf Technol. 2015;82(1):122

[20] Fornell C, Johnson MD, Anderson EW, Cha J, Bryant BE. The American customer satisfaction index: nature, purpose, and findings. J Mark. 1996;60(4):7-18.

[21] Suleiman Awwad M. An application of the American Customer Satisfaction Index (ACSI) in the Jordanian mobile phone sector. TQM J. 2012;24(6):529-41.

[22] Kuo Y-F, Wu C-M, Deng W-J. The relationships among service quality, perceived value, customer satisfaction, and post-purchase intention in mobile value-added services. Comput Human Behav. 2009;25(4):887-96.

[23] Bayraktar E, Tatoglu E, Turkyilmaz A, Delen D, Zaim S. Measuring the efficiency of customer satisfaction and loyalty for mobile phone brands with DEA. Expert Syst Appl. 2012;39(1):99-106.

[24] Carlson J, Rahman MM, Taylor A, Voola R. Feel the VIBE: Examining value-in-the-brand-page-experience and its impact on satisfaction and customer engagement behaviours in mobile social media. J Retail Consum Serv. 2019;46:149-62.

[25] Dovaliene A, Masiulyte A, Piligrimiene Z. The relations between customer engagement, perceived value and satisfaction: The case of mobile applications. Procedia-Social Behav Sci. 2015;213:659-64.

[26] Wang H-Y, Liao C, Yang L-H. What affects mobile application use? The roles of consumption values. Int J Mark Stud. 2013;5(2):11.

[27] Natarajan T, Balasubramanian SA, Kasilingam DL. The moderating role of device type and age of users on the intention to use mobile shopping applications. Technol Soc. 2018;53:79-90.

[28] Yoon H-Y. User acceptance of mobile library applications in academic libraries: an application of the technology acceptance model. J Acad Librariansh. 2016;42(6):687-93

[29] Hsiao C-H, Chang J-J, Tang K-Y. Exploring the influential factors in continuance usage of mobile social Apps: Satisfaction, habit, and customer value perspectives. Telemat Informatics. 2016;33(2):342-55.

[30] Amin M, Rezaei S, Abolghasemi M. User satisfaction with mobile websites: the impact of perceived usefulness (PU), perceived ease of use (PEOU) and trust. Nankai Bus Rev Int. 2014;5(3):258-74.

[31] Lee C-Y, Tsao C-H, Chang W-C. The relationship between attitude toward using and customer satisfaction with mobile application services: an empirical study from the life insurance industry. J Enterp Inf Manag. 2015;28(5):680-97.

[32] DeLone WH, McLean ER. Information systems success: The quest for the dependent variable. Inf Syst Res. 1992;3(1):60-95.

[33] Jalayer M, Zhou H, Zhang B. Evaluation of navigation performances of GPS devices near interchange area pertaining to wrong-way driving. $\mathbf{J}$ Traffic Transp Eng (English Ed. 2016;3(6):593-601.

[34] Thakur R. The role of self-efficacy and customer satisfaction in driving loyalty to the mobile shopping application. Int J Retail Distrib Manag. 2018;46(3):283-303.

[35] Hamidi H, Safareeyeh M. A model to analyze the effect of mobile banking adoption on customer interaction and satisfaction: A case study of m-banking in Iran. Telemat Informatics. 2019;38:166-81.

[36] Iyer P, Davari A, Mukherjee A. Investigating the effectiveness of retailers' mobile applications in determining customer satisfaction and repatronage intentions? A congruency perspective. J Retail Consum Serv. 2018;44:235-43.

[37] Hamidi H, Jahanshaheefard M. Essential factors for the application of education information system using mobile learning: A case study of students of the university of technology. Telemat Informatics. 2019;38:207-24.

[38] Sampaio CH, Ladeira WJ, Santini FDO. Apps for mobile banking and customer satisfaction: a cross-cultural study. Int J Bank Mark. 2017;35(7):1133-53.

[39] Alnawas I, Aburub F. The effect of benefits generated from interacting with branded mobile apps on consumer satisfaction and purchase intentions. J Retail Consum Serv. 2016;31:313-22.

[40] Alqahtani M, Mohammad H. Mobile applications' impact on student performance and satisfaction. Turkish Online J Educ Technol. 2015;14(4):102-12.

[41] Krejcie R V, Morgan DW. Determining Sample Size for Research Activities. 1970;38:607-10.

[42] F. Hair Jr J, Sarstedt M, Hopkins L, G. Kuppelwieser V. Partial least squares structural equation modeling (PLS-SEM) An emerging tool in business research. Eur Bus Rev. 2014;26(2):106-21.

[43] Islam AKM. Information systems Post-adoption satisfaction and dissatisfaction: A study in the e-learning context. PACIS 2011 Proc. 2011 ;

[44] Gorla N, Somers TM, Wong B. Organizational impact of system quality, information quality, and service quality. J Strateg Inf Syst. 2010;19(3):207-28.

[45] Ghasemaghaei M, Hassanein K. Online information quality and consumer satisfaction: The moderating roles of contextual factors-A meta-analysis. Inf Manag. 2015;52(8):965-81.

[46] Chakraborty S, Sengupta K. Structural equation modelling of determinants of customer satisfaction of mobile network providers: Case of Kolkata, India. IIMB Manag Rev. 2014;26(4):234-48.

[47] Chou C-H, Chiu C-H, Ho C-Y, Lee J-C. Understanding Mobile Apps Continuance Usage Behavior and Habit: An Expectance-Confirmation Theory. In: PACIS. 2013. p. 132.

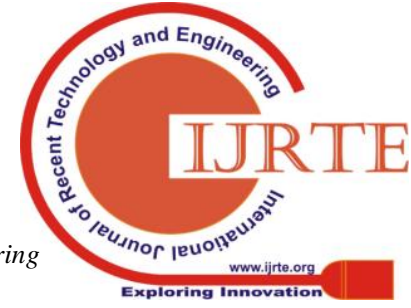


The Success Factors of Mobile GPS Navigation Applications among Tourists in Malaysia

[48] Park E, Kim H, Ohm JY. Understanding driver adoption of car navigation systems using the extended technology acceptance model. Behav Inf Technol. 2015;34(7):741-51.

[49] A, Ahlan., Arshad, Y., Suhaimi, M.A., Hussin, H., IT outsourcing industry practices, models, trends and challenges from a case of a Malaysian offshore global service provider. International Journal of Mathematics And Computers in Simulation, 2008, 89-96. 